\title{
Sinkronisasi Bakat dan Cita-Cita Mahasiswa Angkatan 2016 dalam Memilih Jurusan di Fakultas Sastra Universitas Muslim Indonesia (UMI) Makassar
}

\author{
Muhajir $^{1}$, Rizkariani Sulaiman ${ }^{2}$, Usman Ismail $^{3}$ \\ ${ }^{1}$ Pendidikan Bahasa Inggris, Universitas Muslim Indonesia (UMI) Makassar \\ Email: muhajir.sastra@umi.ac.id. \\ ${ }^{2}$ Pendidikan Bahasa Inggris, Universitas Muslim Indonesia (UMI) Makassar \\ Email: rizka.sulaiman@umi.ac.id. \\ ${ }^{3}$ Sastra Arab, Universitas Muslim Indonesia (UMI) Makassar \\ Email: usman.ismail@umi.ac.id
}

\begin{abstract}
The purpose of this study was to identify the goals of the students 2016 generation at Letters Faculty Universitas Muslim Indonesia which consisting of six programs are English Language and Literature, Indonesian Language and Literature, Arabic Language and Literature, English Language Education, Indonesian Language Education, and Communication Sciences. Quantitative methods with a survey approach are used in this study. The results showed that $62.97 \%$ of students 2016 generation was chose study program based on the compatibility between their talents and interests, and $26.39 \%$ of 2016 generation students at the Letters Faculty was chose study program not adjusted between their talents and interests. Finally, there are $10.64 \%$ of students in 2016 generation who are confused because they do not have goals.
\end{abstract}

Keywords: Talent, Ambition and Choice

\begin{abstract}
Abstrak. Tujuan dari penelitian ini adalah untuk melakukan pemetaan bakat dan pengidentifikasian cita-cita mahasiswa Fakultas Sastra angkatan 2016 yang terdiri dari 6 jurusan yaitu jurusan Sastra Inggris, Sastra Indonesia, Sastra Arab, Pendidikan Bahasa Inggris, Pendidikan Bahasa Indonesia, dan Ilmu Komunikasi. Metode kuantitatif dengan pendekatan survey digunakan dalam penelitian ini. Hasil penelitian menunjukkan bahwa 62.97\% mahasiswa angkatan 2016 memilih jurusan berdasarkan kesesuaian antara bakat dan minatnya, dan 26.39\% mahasiswa pada angkatan 2016 pada Fakultas Sastra memilih jurusan tidak disesuaikan antara bakat dan minatnya. Terakhir, terdapat $10.64 \%$ mahasiswa angkatan 2016 yang mengalami kebingungan karena tidak memiliki cita-cita.
\end{abstract}

Kata Kunci: Bakat, Cita-Cita dan Pilihan

\section{PENDAHULUAN}

Pada era revolusi industri 4.0 sekarang ini, pendidikan masih dipersepsikan hanya sebagai pembentukan intelektual, dan menyebabkan terjadinya kedangkalan dan distorsi identitas lokal dan nasional yang berujung pada krisis moral (Gleason, 2018). Secara global, perubahan dengan liberalisasi pendidikan menuntut lembaga pendidikan untuk mampu menghasilkan kualitas peserta didik yang dapat bersaing secara kompetitif agar dapat 
diterima oleh pasar. Tuntutan untuk memenuhi kebutuhan pasar inilah yang akhirnya akan mendorong suatu lembaga pendidikan lebih menggunakan paradigma yang bercirikan knowledge based economy institution. Pendidikan yang hanya berorientasi untuk mencetak generasi yang dapat diterima pasar secara ekonomis yang menjadi tujuan setiap institusi pendidikan tinggi, sehingga mereka kurang memiliki kecerdasan emosional yang akhirnya bermuara pada terjadinya krisis moral dari peserta didik.

Menghasilkan produk (lulusan) yang dapat diterima oleh pasar secara global bukanlah sebuah perkara mudah karena harus didukung oleh beberapa variabel secara simultan yang menjadi nilai ukur pasar kerja. Salah satu variabel tersebut adalah setiap lulusan perguruan tinggi harus memiliki kompetensi atau berkompeten dibidang keahlian masing-masing yang link and macth dengan pasar kerja. Secara umum, setiap lulusan (sarjana) dari lembaga pendidikan tinggi merupakan sebuah persoalan tersendiri bagi setiap perguruan tinggi di Indonesia termasuk Universitas Muslim Indonesia (UMI) Makassar. Persoalan tersebut akhirnya terefleksi dalam sebuah kasus yang dialami oleh mahasiswa setelah lulus dan menjadi seorang sarjana yaitu tidak terserapnya oleh pasar kerja disebabkan karena tidak memiliki kompetensi berdasarkan disiplin ilmunya.

Berdasarkan data Badan Pusat Statistik (BPS), bahwa jumlah pengangguran sarjana atau lulusan universitas 2013 mencapai 360 ribu orang atau 5,04 persen dari total pengangguran yang mencapai 7,17 juta orang. Sehingga, sarjana atau lulusan perguruan tinggi tidak bisa lagi hanya mengandalkan ijazah dalam mencari pekerjaan tetapi dituntut dan harus memiliki kompetensi atau keterampilan kerja yang baik, sehingga dapat terserap pasar kerja dengan cepat. Kemudian berdasarkan dari data Badan Pusat Statistik (BPS) bulan Februari 2014 mencatat bahwa pengangguran terbuka lulusan universitas di Indonesia berjumlah 398.298 orang. Jumlah itu setara dengan 4,31 persen dari total pengangguran terbuka sebanyak 7.147.069 orang. Saat ini, lebih dari 600.000 lulusan perguruan tinggi Indonesia menganggur. Penganggur intelektual itu sebagian besar lulusan S-1, yakni 420.000 orang, dan sisanya lulusan diploma. Selanjutnya pada bulan Agustus di tahun yang sama yaitu 2014 di Indonesia ada 9,5 persen (688.660 orang) dari total pengangguran yang merupakan alumni perguruan tinggi.

Pada bulan Februari tahun 2015, Badan Pusat Statistik (BPS) mencatat bahwa ada 400.000 sarjana baru lulus dari kampusnya dan berstatus pengangguran. BPS juga mencatat, ada total 7,4 juta pengangguran terbuka per Februari 2015, atau sekitar 5,34 persen total. Ironisnya, kenaikan tersebut sebagian disebabkan sarjana yang lulus lalu menganggur. Kondisi tersebut sangat mengkhawatirkan karena Indonesia telah memasuki Masyarakat Ekonomi ASEAN (MEA). Kemudian, pertanyaan yang muncul adalah mengapa harus MEA yang menjadi acuan pada persoalan tersebut?. Jawabannya adalah sarjana Indonesia tidak hanya akan bersaing dengan sesama anak bangsa, tetapi akan bersaing dengan bangsa asing terutama negara-negara anggota ASEAN. Seterusnya, laporan Badan Pusat Statistik (BPS) mengungkapkan bahwa Tingkat Pengangguran Terbuka (TPT) pada bulan Februari 2016 tercatat sebesar 5,5 persen. Hal tersebut berarti dari 100 angkatan kerja ada sekitar sekitar 5 hingga 6 orang penganggur. Jika dibandingkan dengan kondisi periode sebelumnya yaitu pada bulan Februari tahun 2015, TPT mengalami penurunan sebesar 0,31 persen. Namun demikian, TPT untuk lulusan universitas atau sarjana (S1) justru mengalami peningkatan yang 
cukup signifikan. Terdata tingkat pengangguran terdidik lulusan Sarjana meningkat dari 5,34 persen pada bulan Februari 2015 naik menjadi 6,22 persen di bulan Februari 2016.

Berdasarkan pada uraian tersebut menunjukkan bahwa dalam menghasilkan lulusan yang dapat diterima oleh pasar harus didukung oleh beberapa variabel secara sinkron diantaranya adalah variabel bakat dan cita-cita yang dapat menghasilkan lulusan yang memiliki kompetensi secara profesional. Pada permasalahan tersebut dapat diidentifikasi satu permasalahan yaitu apakah lulusan (sarjana) tersebut ketika masih mahasiswa memilih jurusan berdasarkan pada bakat dan cita-citanya.

\section{Multiple Intelligences}

Pada umumnya, intelegensi dapat dilihat dari kesanggupan seseorang dalam besikap dan berbuat sesuai dengan situasi. Menurut Cohen, D. K. (1999) bahwa intelegensi merupakan suatu kemampuan tertinggi dari makhluk hidup yang hanya dimiliki manusia dan dibawa sejak lahir untuk menyesuaikan diri terhadap setiap situasi. Sehingga inteligensi merupakan kapasitas kesatuan dari penalaran logis yang merupakan kemampuan abstraksi sangat bernilai (Gardner, H., 1983). Oleh karena itu, inteligensi sebagai kekuatan mental yang muncul dalam aktifitas intelektual dan dapat digambarkan dalam berbagai tingkatan. Sehingga inteligensi meliputi beberapa kemampuan mental.

Menurut Gardner, H. (1983) bahwa dasar intelegensi terdiri dari pengembangan dari kecerdasan otak (IQ), kecerdasan emosional (EQ), dan kecerdasan spiritual (SQ) yang disebut Multiple Intelligences sebagai dasar pengembangan delapan kecerdasan. Secara jelas, Gardner, H. (1983) mengungkapkan bahwa kecerdasan bukanlah sesuatu yang bersifat tetap dan bukanlah unit kepemilikan tunggal. Namun kecerdasan merupakan serangkaian kemampuan dan keterampilan yang dapat dikembangkan karena kecerdasan ada pada setiap manusia tetapi dengan tingkat yang berbeda-beda (Craig, J. B. (2008). Sehingga Joyce, B., dan Showers, B. (2002) mendefinisikan kecerdasan sebagai keseluruhan kemampuan individu untuk berfikir dan bertindak secara terarah serta mengolah dan menguasai lingkungan secara efektif.

Teori Multiple Intelligences bertujuan untuk mentransformasikan agar dapat mengakomodasi setiap mahasiswa dengan berbagai macam pola pikirnya yang unik. Oleh karena itu, ada beberapa macam kecerdasan yang diungkapkan oleh Howard Gardner yaitu (1) kecerdasan linguistik, (2) kecerdasan logis matematis, (3) kecerdasan spasial, (4) kecerdasan kinestetis, (5) kecerdasan musikal, (6) kecerdasan interpersonal, (7) kecerdasan intrapersonal, (8) kecerdasan naturalis. Berdasarkan teori dari Multiple Intelligences bahwa tiga dasar utama intelegensi yaitu kecerdasan otak (IQ), kecerdasan emosional (EQ), dan kecerdasan spiritual (SQ) yang secara detail dapat mengakomodasi delapan kecerdasan sebagai dasar mensinkronkan antara bakat dan cita-cita seseorang.

\section{Minat}

Minat merupakan sebagai kesukaan dan kecenderungan hati terhadap suatu keinginan. Menurut Bilz, J. (2008) bahwa minat adalah suatu perasaan yang lebih cenderung atau suka kepada sesuatu hak atau aktifitas tanpa ada yang menyuruh. Namun menurut 
Guskey, T. R. (2000) bahwa minat secara sederhana adalah perhatian yang mengandung unsur-unsur perasaan. Oleh karena itu, melihat minat sebagai suatu perangkat mental yang terdiri dari suatu campuran dari perasaan, harapan, pendirian, prasangka takut atau kecenderungan lain yang mengarahkan individu kepada suatu pilihan tertentu. Menurut Bratton, J., \& Gold, J. (2000) bahwa minat muncul dalam pikologis mahasiswa merupakan sebuah gejala, sehingga munculnya minat tersebut dipengaruhi oleh beberapa faktor yang menjadi penyebabnya yaitu faktor individu dan sosial. Faktor individu merupakan pengaruh yang muncul dalam diri mahasiswa secara alami, misalnya diakibatkan karena kematangan, kecerdasan, latihan, motivasi dan sifat pribadi. Setiap individu mempunyai tingkat kematangan serta kecerdasan yang berbeda, sehingga minat yang muncul juga tidak sama antara individu satu dengan yang lain. Oleh karena itu, seseorang yang mempunyai kecerdasan dibidang mata pelajaran ekonomi maka akan cenderung melakukan aktifitas bisnis jual beli.

Selanjutnya, faktor sosial merupakan pengaruh yang muncul diluar individu dan biasanya diakibatkan karena kondisi keluarga, lingkungan, pendidikan dan motivasi sosial. Misalnya ketika siswa hidup dalam masyarakat yang kesehariannya bersentuhan dengan padi (mayoritas petani padi), maka seseorang cenderung ingin tahu dan mengenal kegiatan tersebut karena merasa menjadi bagian dari itu. Jadi, peran minat sangat besar jika dikaitkan dalam pelaksanaan pembelajaran karena dengan adanya minat mahasiswa untuk belajar, proses pembelajaran akan dapat efektif. Oleh karena itu, mahasiswa telah berminat dalam kegiatan belajar mengajar, maka hampir dapat dipastikan proses belajar mengajar akan berjalan dengan baik dan hasil belajar juga optimal, sehingga memberikan implikasi positif pengembangan bakat seseorang.

\section{Bakat}

Bakat atau aptitude merupakan kecakapan potensial yang bersifat khusus dalam sesuatu bidang atau kemampuan tertentu (Lucy, 2010). Menurut Wijanarko. (2012) bahwa seseorang lebih berbakat dalam bidang bahasa dan yang lain dalam matematika dan yang lainnya juga lebih menunjukkan bakatnya dalam sejarah dan sebagainya. Menurut Guskey, T. R. (2000) bahwa bakat memungkinkan seseorang mencapai prestasi tertentu dalam bidang tertentu, tetapi diperlukan latihan, pengetahuan, pengalaman dan dorongan atau motivasi agar dapat terwujud. Misalnya, seseorang memiliki bakat menggambar, jika tidak pernah diberi kesempatan untuk mengembangkan, maka bakat tersebut tidak akan tampak. Jika orang tuanya menyadari bahwa anaknya mempunyai bakat menggambar dan mengusahakan agar dapat pengalaman yang baik untuk mengembangkan bakatnya, dan anak itu juga menunjukkan minat yang besar untuk mengikuti pendidikan menggambar, maka anak tersebut akan dapat mencapai prestasi unggul untuk bidang tersebut (Joyce, B., \& Showers, B., 2002).

Dalam kehidupan di sekolah sering tampak bahwa seseorang yang bakat dalam olahraga, umumnya prestasi mata pelajarannya juga baik, tetapi sebaliknya dapat terjadi prestasi semua mata pelajarannya tidak baik. Keunggulan dalam salah satu bidang apakah bidang sastra, seni atau matematika, merupakan hasil interaksi dari bakat yang dibawa sejak lahir dan faktor lingkungan yang menunjang termasuk minat dan motivasi. 


\section{METODE PENELITIAN}

Penelitian survei biasanya digunakan dalam ilmu sosial untuk membantu melakukan pengamatan terhadap suatu fenomena sosial (Morison, 2014). Pada penelitian tentang pemetaan bakat dan cita-cita mahasiswa angkatan 2016 Fakultas Sastra Universitas Muslim Indonesia (UMI) menggunakan metode penelitian kuantitatif dengan pendekatan survei. Sampel dalam penelitian ini adalah 50\% dari jumlah mahasiswa angkatan 2016 (populasi) yang terdiri dari enam program studi di Fakultas Sastra UMI.

\section{HASIL DAN PEMBAHASAN}

Bakat merupakan sebuah variabel sekaligus instrumen untuk memberikan gambaran tentang potensi yang dimiliki seseorang secara non-fisik (Cranton, P., 2006; Seifert, K., \& Sutton, R. 2009). Sehingga deskripsi tentang bakat seseorang akan memberikan gambaran dasar potensi yang berimplikasi pada kejelasan tentang apa yang harus dilakukan berdasarkan potensi bakat tersebut. Kemudian cita-cita merupakan sebuah variabel yang dapat memberikan gambaran tentang apa yang harus dilakukan untuk merealisasikan cita-cita, sehingga melalui sebuah cita-cita seseorang dapat menentukan apa yang harus dilakukan. Oleh karena itu, kesesuaian keduanya antara bakat dan cita-cita sangat jelas berimplikasi pada masa depan seseorang termasuk setiap mahasiswa di Fakultas Sastra Universitas Muslim Indonesia. Secara jelas, mahasiswa Fakultas Sastra terdiri dari enam jurusan akan diuraikan berdasarkan data hasil penelitian.

\section{Jurusan Sastra Inggris Angkatan 2016}

Berdasarkan data hasil penelitian tentang sinkronisasi bakat dengan cita-cita mahasiswa yang telah dilakukan dengan melibatkan $50 \%$ dari total jumlah mahasiswa jurusan Sastra Inggris angkatan 2016 menujukkan bahwa terdapat 26.15\% mahasiswa jurusan Sastra Inggris angkatan 2016 memilih jurusan tersebut tidak didasarkan pada kesesuaian bakat dengan cita-citanya. Kemudian, 60\% mahasiswa angkatan 2016 telah memilih jurusan Sastra Inggris berdasarkan kesesuaian bakat dengan cita-citanya. Selanjutnya, ada $13.85 \%$ mahasiswa jurusan Sastra Inggris angkatan 2016 yang mengalami kebingunan karena tidak memiliki cita-cita. Secara lengkap, hasil penelitian tentang kesesuaian bakat dengan cita-cita mahasiswa jurusan Sastra Inggris angkatan 2016 dapat dilihat pada tabel berikut:

\begin{tabular}{ccc}
\hline \multicolumn{3}{c}{ Jurusan Sastra Inggris - Angkatan 2016 } \\
\hline & Bakat dengan Cita-Cita \\
\hline Sesuai & Tidak Sesuai & Bingung \\
\hline $60 \%$ & $26.15 \%$ & $13.85 \%$ \\
\hline & Total 100\% & \\
\hline
\end{tabular}

Sinkronisasi antara potensi bakat dengan cita-cita mahasiswa jurusan Sastra Inggris angkatan 2016 dapat memberikan gambaran secara dominan tentang ketercapaian sebuah cita-cita karena didasarkan pada sebuah bakat (Basleman, A., \& Mappa, S., 2011). Data tersebut menunjukkan presentase diatas $50 \%$ yaitu $60 \%$ mahasiswa memilih jurusan Sastra Inggris telah sesuai bakat dan cita-citanya. Sehingga memberikan gambaran secara dominan 
bahwa diatas 50\% mahasiswa jurusan Sastra Inggris angkatan 2016 akan dapat mencapai citacitanya karena didukung oleh potensi bakat.

Menurut Craig, (2008) bahwa terjadinya ketidaksesuaian bakat dan cita-cita akan berimplikasi pada masa depan seseorang mengenai apa yang direncanakan. Begitu pula bahwa 26.15\% mahasiswa jurusan Sastra Inggris angkatan 2016 akan sulit mencapai citacitanya karena memilih jurusan tersebut tidak didasarkan pada bakat. Oleh karena itu, citacita yang ideal dapat dicapai melalui beberapa faktor diantaranya bakat.

\section{Jurusan Sastra Indonesia Angkatan 2016}

Data hasil penelitian menunjukkan bahwa terdapat 3\% dari total sampel (mahasiswa jurusan Sastra Indonesia angkatan 2016) yang memilih jurusan tersebut tidak didasarkan pada kesesuaian bakat dan cita-citanya. Kemudian terdapat $76.9 \%$ mahasiswa yang memiliki potensi bakat sesuai dengan cita-citanya dan tidak ditemukan mahasiswa jurusan Sastra Indonesia yang tidak memiliki cita-cita. Secara jelas, dapat dilihat pada tabel berikut:

\begin{tabular}{ccc}
\hline \multicolumn{3}{c}{ Jurusan Sastra Indonesia - Angkatan 2016 } \\
\hline & Bakat dengan Cita-Cita \\
\hline Sesuai & Tidak Sesuai & Bingung \\
\hline $76.9 \%$ & $23.1 \%$ & $0 \%$ \\
\hline & Total 100\% & \\
\hline
\end{tabular}

Hasil penelitian ini memberikan gambaran bahwa mahasiswa jurusan Sastra Indonesia angkatan 2016 secara dapat memberikan gambaran secara dominan tentang ketercapaian sebuah cita-cita karena didasarkan pada sebuah bakat yaitu $76.9 \%$. Namun demikian, hanya $23.1 \%$ mahasiswa pada jurusan tersebut yang akan mengalami kesulitan merealisasikan citacitanya.

\section{Jurusan Sastra Arab Angkatan 2016}

Mengacu pada data hasil penelitian tentang pemetaan potensi bakat dengan menggunakan teori Multiple Intelegency oleh Howard Garnerd yang didasarkan pada delapan standar bakat pada mahasiswa jurusan Sastra Arab angkatan 2016 menunjukkan bahwa hanya $20 \%$ mahasiswa memilih jurusan tersebut berdasarkan potensi bakat disesuaikan dengan cita-citanya, dan $30 \%$ mahasiswa dari jurusan tersebut memilih jurusan tidak didasarkan pada bakat dengan cita-citanya. Secara ekstrem bahwa 50\% mahasiswa jurusan Sastra Arab angkatan 2016 yang mengalami kebingungan disebabkan karena tidak memiliki cita-cita. Secara jelas, dapat dilihat pada berikut:

\begin{tabular}{ccc}
\hline \multicolumn{3}{c}{ Jurusan Sastra Arab - Angkatan $\mathbf{2 0 1 6}$} \\
\hline & Bakat dengan Cita-Cita \\
\hline Sesuai & Tidak Sesuai & Bingung \\
\hline $20 \%$ & $30 \%$ & $50 \%$ \\
\hline & Total 100\% & \\
\hline
\end{tabular}


Berdasarkan hasil penelitian tentang kesesuaian antara bakat dengan cita-cita mahasiswa jurusan Sastra Arab angkatan 2016 menunjukkan presentase $20 \%$ mahasiswa yang sesuai bakat dan cita-citanya, dan 30\% mahasiswa memilih jurusan tersebut pada tahun 2016 akan sulit mencapai cita-citanya. Secara mengejutkan bahwa terdapat $50 \%$ mahasiswa pada jurusan tersebut tidak memiliki cita-cita, sehingga tidak bisa menentukan apa yang dilakukan.

\section{Jurusan Pendidikan Bahasa Inggris}

Data hasil penelitian tentang pemetaan bakat dan pengidentifikasian cita-cita dengan menggunakan teori Howard Garnerd pada mahasiswa jurusan Pendidikan Bahasa Inggris angkatan 2016 menunjukkan bahwa terdapat 69.1\% mahasiswa yang telah memiliki kesesuaian bakat dengan cita-citanya, dan terdapat $25.4 \%$ mahasiswa yang tidak memiliki kesesuaian. Kemudian hanya 5.5\% mahasiswa pada jurusan tersebut yang mengalami kebingungan dalam hal penentuan cita-cita. Secara jelas, dapat dilihat pada tabel berikut:

\begin{tabular}{ccc}
\hline \multicolumn{3}{c}{ Jurusan Pend. Bahasa Inggris - Angkatan 2016 } \\
\hline \multicolumn{3}{c}{ Bakat dengan Cita-Cita } \\
\hline Sesuai & Tidak Sesuai & Bingung \\
\hline $69.1 \%$ & $25.4 \%$ & $5.5 \%$ \\
\hline
\end{tabular}

Data tersebut memberikan gambaran kedepan bahwa potensi mahasiswa jurusan Pendidikan Bahasa Inggris angkatan 2016 diatas 50\% yaitu 69.1\% akan dapat merealisasikan atau mencapai cita-citanya karena didukung oleh bakat.

\section{Jurusan Pendidikan Bahasa Indonesia}

Hasil penelitian tentang pemetaan bakat dan cita-cita pada mahasiswa Pendidikan Bahasa Indonesia angkatan 2016 menunjukkan bahwa terdapat 66.6\% mahasiswa yang telah memiliki kesesuaian bakat dengan cita-citanya, dan terdapat $33.4 \%$ mahasiswa pada jurusan tersebut yang tidak sesuai bakat dengan cita-citanya dalam memilih jurusan tersebut. Secara jelas, dapat dilihat pada tabel berikut:

\begin{tabular}{ccc}
\hline \multicolumn{3}{c}{ Jurusan Pend. Bahasa Indonesia - Angkatan 2016 } \\
\hline \multicolumn{3}{c}{ Bakat dengan Cita-Cita } \\
\hline Sesuai & Tidak Sesuai & Bingung \\
\hline $66.6 \%$ & $33.4 \%$ & $0 \%$ \\
\hline
\end{tabular}

Secara jelas dapat disimpulkan bahwa kesesuaian bakat dengan cita-cita mahasiswa jurusan Pendidikan Bahasa Indonesia angkatan 2016 bahwa presentase 66.6\% mahasiswa pada jurusan tersebut sesuai dengan bakat dan cita-citanya, sehingga memberikan kemudahan secara signifikan mahassiswa tersebut untuk dapat merealisasikan cita-citanya. 


\section{Jurusan IImu Komunikasi}

Merujuk pada data penelitian tentang pemetaan bakat dengan teori delapan standar bakat pada mahasiswa jurusan IImu Komunikasi angkatan 2016 menunjukkan bahwa 63.6\% mahasiswa telah sesuai bakat dengan cita-cita dalam memilih jurusan tersebut, dan terdapat 25.5\% mahasiswa pada jurusan tersebut tidak sesuai bakat dengan cita-citanya. Kemudian terdapat 10.9\% mahasiswa jurusan Ilmu Komunikasi angkatan 2016 yang mengalami kebingungan dan tidak memiliki cita-cita. Secara jelas, dapat dilihat pada tabel berikut:

\begin{tabular}{ccc}
\hline \multicolumn{3}{c}{ Jurusan Ilmu Komunikasi - Angkatan 2016 } \\
\hline & Bakat dengan Cita-Cita \\
\hline Sesuai & Tidak Sesuai & Bingung \\
\hline $63.6 \%$ & $25.5 \%$ & $10.9 \%$ \\
\hline & Total 100\% \\
\hline
\end{tabular}

Secara umum, kesesuaian antara potensi bakat dengan cita-cita mahasiswa jurusan Ilmu Komunikasi angkatan 2016 dapat memberikan gambaran tentang ketercapaian sebuah cita-cita karena didasarkan pada sebuah bakat. Temuan tersebut memberikan gambaran bahwa dibawah hanya 25.5\% mahasiswa jurusan Ilmu Komunikasi angkatan 2016 yang tidak sesuai bakat dan cita-citanya dalam memilih jurusan tersebut.

\section{KESIMPULAN}

Berdasarkan hasil penelitian yang telah dilakukan tentang pemetaan bakat dan pengidentifikasian minat dalam mensinkrinisasikan keduanya sebagai dasar pemilihan jurusan di Fakultas Sastra Universitas Muslim Indonesia pada angkatan 2016 dapat disimpulkan bahwa :

1. Terdapat $62.97 \%$ mahasiswa angkatan 2016 pada Fakultas Sastra Universitas Muslim Indonesia memilih jurusan didasarkan pada sinkronisasi atau kesesuaian antara bakat dan minat.

2. Terdapat $26.39 \%$ mahasiswa angkatan 2016 pada Fakultas Sastra Universitas Muslim Indonesia memilih jurusan tidak didasarkan pada kesesuaian antara bakat dan minat.

3. Terdapat $10.65 \%$ mahasiswa angkatan 2016 pada Fakultas Sastra Universitas Muslim Indonesia mengalami kebingunan mengapa memilih jurusan tersebut karena mereka tidak memiliki cita-cita.

4. Secara umum, diatas $50 \%$ yaitu 62.97 mahasiswa angkatan 2016 pada Fakultas Sastra akan mengalami kemudahan dalam mendapatkan pekerjaan karena mereka memilih jurusan didasarkan pada kesesuaian bakat dan minatnya. 


\section{DAFTAR PUSTAKA}

Basleman, A., dan Mappa, S. (2011). Teori Belajar Orang Dewasa. Bandung: PT. Remaja Rosdakarya.

Bilz, J. (2008). Job Satisfaction and Teacher Career Stages. Unpublished PhD Dissertation, United Stated Code, Walden University.

Badan Pusat Statistik. (2013). Tingkat Pengangguran Terbuka. Retrieved 20-02, 2017, from https://www.bps.go.id/dataset.

Badan Pusat Statistik. (2014). Tingkat Pengangguran Terbuka. Retrieved 20-02, 2017, from https://www.bps.go.id/dataset.

Badan Pusat Statistik. (2015). Tingkat Pengangguran Terbuka. Retrieved 20-02, 2017, from https://www.bps.go.id/dataset.

Badan Pusat Statistik. (2016). Tingkat Pengangguran Terbuka. Retrieved 20-02, 2017, from https://www.bps.go.id/dataset.

Bratton, J., dan Gold, J. (2000). Human Resource Management: Theory and practice. Mahwah, New Jersey: Lawrence Erlbaum Associates, Inc.

Craig, J. B. (2008). The Relationship Between the Emotional Intelligence of the Principal and Teacher Job Satisfaction. Unpublished Dissertation, United Stated Code, University of Pennsylvania.

Cranton, P. (2006). Understanding and promoting transformative learning: a guide for educators of Adults ( $2^{\text {nd }}$ ed.). San Francisco, CA: Jossey-Bass.

Guskey, T. R. (2000). Evaluating Professional Development. Thousand Oaks, California: Corwin Press Incorporated.

Joyce, B., dan Showers, B. (2002). Student Achievement through Staff Development Fundamentals of School Renewal ( $3^{\text {rd }}$ ed.). USA: Longman, Inc.

Lucy, Bunda. 2010. Mendidik Sesuai Minat dan Bakat Anak (Painting Your Children's Future). Jakarta: PT. Tangga Pustaka.

McClelland, D. (1961). The Achieving Society. Princeton, New Jersey, Toronto, New York: D. Van Nostrand Company, Inc.

Morissan. 2014. Metode Penelitian Survei. Jakarta: Prenada Media.

Seifert, K., dan Sutton, R. (2009). Educational Psychology ( $2^{\text {nd }}$ ed.). Zurich, Switzerland: The Global Text Project.

Tilaar, H. A. R. (2004). Beberapa Agenda Reformasi Pendidikan Nasional (dalam Perspektif abad 21). Magelang; Tera Indonesia.

Wijanarko, Jarot. 2012. Multiple Intelligences Anak Cerdas. Banten: PT. Happy Holy Kids. 